\title{
MENINGKATKAN PRESTASI BELAJAR DAN KEAKTIFAN MAHASISWA MELALUI PROJECT BASED LEARNING
}

\author{
${ }^{1)}$ Harry Dwi Putra, ${ }^{2}$ Ratni Purwasih \\ ${ }^{1)}$ harrydp.mpd@gmail.com, ${ }^{2)}$ ratnipurwasih61@gmail.com \\ ${ }^{1,2)}$ Program Studi Pendidikan Matematika, STKIP Siliwangi
}

\begin{abstract}
ABSTRAK
Prestasi belajar dan keaktifan mahasiswa penting untuk ditingkatkan dalam proses pembelajaran, sehingga diperlukan suatu model pembelajaran yang inovatif. Dari begitu banyak model pembelajaran inovatif, salah satu yang tepat untuk meningkatkan prestasi belajar dan keaktifan mahasiswa adalah pembelajaran berbasis proyek (project based learning), karena lebih menekankan pada pendekatan kontekstual melalui kegiatan-kegiatan yang kompleks, melibatkan mahasiswa dalam melakukan investigasi pemecahan masalah dan kegiatan bermakna, memberi kesempatan bekerja secara mandiri dalam mengkontruksi pengetahuan, serta menghasikan produk nyata. Penelitian ini merupakan kuasi eksperimen dengan menggunakan kelompok eksperimen dan kontrol. Instrumen yang digunakan adalah tes hasil belajar dan lembar observasi keaktifan mahasiswa. Penelitian dilaksanakan di dua kelas reguler angkatan 2014 program studi pendidikan matematika STKIP Siliwangai Bandung. Subjek penelitian berjumlah 120 mahasiswa yang terbagi di kelas A1 dan A3. Teknik pengambilan sampel dilakukan secara purposive, karena penelitian ini diterapkan pada mahasiswa di kelas yang mengambil mata kuliah media pembelajaran matematika. Berdasakan analisis data, diperoleh rerata peningkatan prestasi belajar kelas eksperimen dan kontrol masing-masing sebesar 84,57 dan 72,79. Persentase keaktifan mahasiswa kelas eksperimen dan kontrol masing-masng sebesar 70,93\% dan 69,41\%. Dapat disimpulkan bahwa prestasi belajar dan keaktifan mahasiswa yang memperoleh pembelajaran dengan project based learning lebih baik daripada yang memperoleh pembelajaran dengan metode ekspositori.
\end{abstract}

Kata Kunci: Prestasi Belajar, Keaktifan, dan Project Based Learning.

\begin{abstract}
Learning and student achievement is important for the enhanced activity of the learning process, so we need a model of innovative learning. Of so many innovative learning model, one that is appropriate to improve learning achievement and activity of students is project-based learning (project based learning), as more emphasis on contextual approach through activities that are complex, involve students in an investigation of problem solving and activities meaningful, giving the opportunity to work independently in the construct knowledge, as well as generate real products. This is a quasi-experimental study using experimental and control groups. The instrument used was a test of learning outcomes and student observation sheet liveliness. The research was conducted in two regular class 2014 of mathematics education courses STKIP Siliwangai Bandung. Subjects numbered 120 students, divided in classes A1 and A3. The sampling technique was done by purposive, because this study applied to the students in the class were taking courses in mathematics learning media. Based on data analysis, obtained a mean improvement of learning achievement of the experimental and control classes respectively by 84.57 and 72.79. Activeness percentage grade students experiment and control each masng amounted to $70.93 \%$ and $69.41 \%$. It can be concluded that the achievement of learning and activity of students who receive study with project-based learning is better than the gain of learning with expository method.
\end{abstract}

Key Words: Achievement, Activeness, and Project Based Learning.

\section{A. PENDAhULUAN}

Aktivitas pembelajaran dalam perkuliahan merupakan interaksi aktif antara dosen dan mahasiswa.Tugas dan tanggung jawab seorang dosen adalah mengelola pembelajaran dengan efektif, dinamis, dan efisien yang ditandai dengan adanya keterlibatan aktif dari mahasiswa.Dosen memberikan bimbingan dan arahan kepada mahasiswa untuk aktif mencari informasi tentang 
materi yang dipelajari.Mahasiswa mesti mengkonstruksi sendiri pengetahuan yang diperolehnya, karena pengetahuan merupakan konstruksi dari seseorang yang mengetahui sehingga tidak bisa ditransfer begitu saja kepada penerima yang pasif.

Namun, pada pelaksanaan perkuliahan, masih ada dosen yang selalu menyajikan dan menerangkan materi pelajaran, sedangkan mahasiswa hanya mencatat dan memperhatikan. Aktivitas pembelajaran seperti ini akan membuat mahasiswa menjadi pasif, karena mereka tidak diminta untuk mempelajari terlebih dahulu materi yang akan dipelajari, sehingga ketika dosen menerangkan, mahasiswa tidak memiliki bekal pengetahuan untuk didiskusikan bersama di kelas. Akan lebih baik apabila mahasiswa mencoba mempelajari materi terlebih dahulu, kemudian mempresentasikan hasil pekerjaannya di depan kelas, dan saling berdiskusi dengan mahasiswa lainnya, sehingga suasana perkuliahan menjadi aktif dan dinamis dengan bimbingan dan arahan dosen.

Keaktifan mahasiswa merupakan bagian penting dalam proses perkuliahan, karena pengetahuan dapat dimiliki jika dipelajari terlebih dahulu. Belajar adalah berbuat, sehingga ada aktivitas dalam pembelajaran.Dosen menyediakan bahan ajar, sedangkan mahasiswa mencari dan mendalami bahan tersebut sesuai dengan kemauan dan kemampuannya.Sudjana (2005) mengemukakan bahwa pembelajaran yang berhasil di antaranya dapat dilihat dari kegiatan belajar.Semakin tinggi kegiatan belajar mahasiswa, semakin tinggi pula peluang berhasilnya pembelajaran.

Berdasarkan pengalaman penulis ketika mengajar pada semester ganjil 2014/2015 yang lalu, sebagian besar mahasiswa kurang terlibat aktif dalam pembelajaran, hal ini terlihat dari 14 pertemuan, rerata keaktifan 58 mahasiswa kelas A1 sebesar 1,70, sedangkan rerata keaktifan 54 mahasiswa kelas A1 sebesar 1,41. Data ini menunjukkan bahwa keaktifan mahasiswa selama pembelajaran jauh dari harapan.Apabila mahasiswa diminta secara sukarela untuk tampil mempresentasikan hasil pekerjaan di depan kelas, sangat sedikit sekali yang bersedia. Kondisi ini antara lain disebabkan karena mereka belum terbiasa tampil di depan kelas berbagi informasi dengan teman yang lain atau belum menguasai materi yang akan disampaikan. Oleh karena itu, dosen perlu memberikan motivasi bahwa bagi mereka yang berpartisipasi aktif selama perkuliahan akan memperoleh nilai yang baik.

Keaktifan mahasiswa akan mempengaruhi keberhasilannya dalam perkuliahan. Mahasiswa yang belajar dengan aktif, akan memiliki pemahaman konsep yang baik, karena mereka telah mempelajari materi terlebih dahulu sebelum didiskusikan dengan teman dan dosen di kelas. Mahasiswa yang selalu melakukan usaha belajar seperti ini hingga akhir perkuliahan, akan memperoleh prestasi belajar yang memuaskan. Prestasi belajar merupakan hasil yang dicapai mahasiswa setelah mendapat pengajaran pada kurun waktu tertentu.Prestasi belajar merupakan cerminan dari usaha belajar. Apabila mahasiswa giat berusaha dalam belajar, maka akan memperoleh prestasi belajar yang baik.

Namun, kenyataan penulis ketika mengajar pada semester Ganjil 2014/2015 lalu, prestasi belajar mahasiswa masih kurang memuaskan. Dari 58 mahasiswa A1 sekitar 56,90\% yang memperoleh nilai maksimal dan dari 54 mahasiswa A2 hanya sekitar 45,28\%. Sebagian besar dari mahasiswa yang memperoleh nilai maksimal tersebut aktif dalam perkuliahan, selebihnya merupakan mahasiswa yang tidak aktif dengan nilai sedang dan rendah.

Mengingat begitu pentingnya meningkatkan prestasi belajar dan keaktifan mahasiswa, perlu diupayakan suatu model pembelajaran yang inovatif.Dari begitu banyak model pembelajaran inovatif, salah satu yang tepat untuk meningkatkan prestasi belajar dan keaktifan mahasiswa adalah pembelajaran berbasis proyek (project based learning). Thomas (Wena, 2011) menyatakan bahwa project based learningmerupakan sebuah pembelajaran inovatif yang lebih menekankan pada pendekatan kontekstual melalui kegiatankegiatan yang kompleks, melibatkan mahasiswa dalam melakukan investigasi pemecahan masalah dan kegiatan bermakna, memberi kesempatan bekerja secara mandiri dalam mengkonstruksi pengetahuan, serta menghasilkan produk nyata.

Model pembelajaran project based learning sesuai diterapkan pada mata kuliah media pembelajaran matematika, karena mahasiswa diminta menciptakan suatu alat peraga yang efektif dan efisien guna membantu siswa sekolah menengah dalam memahami materi matematika. Sebelum perkuliahan, mahasiswa secara mandiri mencari dan mempelajari materi yang akan dibahas, salah 
satu mahasiswa akan dipilih secara acak untuk mempersiapkan diri tampil mempresentasikan hasil pekerjaannya. Diharapkan dengan model pembelajaran project based learning ini dapat meningkatkan prestasi belajar dan keaktifan mahasiswa.

Rumusan masalah dalam penelitian ini, yaitu: (1) apakah peningkatan prestasi belajar mahasiswa yang memperoleh pembelajaran dengan projectbased learning lebih baik daripada yang memperoleh pembelajaran dengan metode ekspositori? dan (2) apakah keaktifan mahasiswa yang memperoleh pembelajaran dengan projectbased learning lebih baik daripada yang memperoleh pembelajaran dengan metode ekspositori? Sedangkan, tujuan dari penelitian ini adalah untuk menelaah prestasi belajar dan keaktifan mahasiswa yang memperoleh pembelajaran dengan projectbased learning dan yang memperoleh pembelajaran dengan metode ekspositori.

\section{B. KAJIAN TEORI DAN METODE}

\section{Kajian Teori}

\section{a. Prestasi Belajar}

Dalam Kamus Besar Bahasa Indonesia, prestasi berarti hasil yang telah dicapai. Menurut Azwar (1998), prestasi merupakan hasil belajar yang dicapai dari apa yang telah dikerjakan secara optimal. Sardiman (2006) menyatakan bahwa prestasi adalah kemampuan nyata yang merupakan hasil interaksi antara berbagai faktor yang mempengaruhi, baik dari dalam maupun dari luar individu ketika belajar.Dari pendapat tersebut, dapat disimpulkan bahwa prestasi merupakan suatu hal yang telah dicapai sebagai usaha yang telah dilakukan.

Belajar merupakan proses untuk mengetahui sejauh mana materi pelajaran yang disampaikan dapat diterima dan dipahami, sehingga prestasi belajar dapat dinyatakan dalam bentuk nilai dari hasil tes. Menurut Poerwadarminta (2006), prestasi belajar adalah hasil yang dicapai sebaik-baiknya menurut kemampuan anak pada waktu tertentu terhadap hal-hal yang dikerjakan. Dalyono (2005) mengungkapkan beberapa faktor yang mempengaruhi prestasi belajar, yaitu faktor iternal dan eksternal.Faktor internal berupa kesehatan, kecerdasan, bakat, minat, dan motivasi.Faktor eksternal berupa keluarga, sekolah, masyarakat, dan lingkungan sekitar.

\section{b. Keaktifan Belajar}

Keaktifan berasal dari kata aktif, menurut Kamus Besar Bahasa Indonesia berarti giat bekerja atau berusaha. Hamalik (2006) mendefinisikan keaktifan sebagai adanya keinginan untuk berbuat dan bekerja sendiri.Keaktifan dalam belajar terlihat dari kegiatan berbuat sesuatu untuk memahami materi pelajaran.Dierich (Hamalik, 2006) mengklasifikasikan keaktifan belajar, sebagai berikut:

1) Kegiatan visual, seperti membaca, melihat gambar, mengamati eksperimen, demonstrasi, mengamati orang lain bekerja, bermain, dsb.

2) Kegiatan lisan, seperti mengemukakan suatu fakta atau prinsip, menghubungkan suatu kejadian, mengajukan pertanyaan, memberi saran, mengemukakan pendapat, wawancara, berdiskusi, dsb.

3) Kegiatan mendengarkan, seperti mendengarkan penyajian bahan, mendengarkan percakapan atau diskusi kelompok, mendengarkan suatu instrumen musik, mendengarkan siaran radio, dsb.

4) Kegiatan menulis, seperti menulis cerita, laporan, karangan, dsb.

5) Kegiatan metrik, seperti melakukan percobaan, memilih alat-alat, melaksanakan pameran, membuat model, melakukan stimulasi, menari, berkebun, dsb.

6) Kegiatan menggambar, seperti membuat diagram, grafik, peta, pola, dsb.

7) Kegiatan mental, seperti merenung, mengingat, memecahkan masalah, menganalisis faktorfaktor, menemukan hubungan-hubungan, membuat keputusan, dsb.

8) Kegiatan emosional, seperti minat, membedakan, berani, tenang, dsb.

Cara yang dapat dilakukan untuk meningkatkan keaktifan mahasiswa (Usman, 2002), antara lain:

a) Dalam kegiatan pembelajaran, buatlah suatu kondisi yang dapat membuat mahasiswa merespon secara aktif.

b) Pada masa transisi dalam kegiatan belajar sebaiknya dilakukan secara cepat dan luwes, sehingga fokus mahasiswa dalam pembelajaran tetap terjaga.

c) Gunakan metode yang dapat mendukung tujuan pembelajaran.

d) Ciptakan pembelajaran yang menumbuhkan minat mahasiswa. 
Dalam aktivitas perkuliahan, terdapat interaksi antara mahasiswa dan dosen. Lidgren (Usman, 2002) mengklasifikasikan empat jenis interaksi dalam kegiatan belajar mengajar, sebagai berikut:

(1) Komunikasi satu arah. Komunikasi hanya dilakukan oleh dosen, sementara mahasiswa hanya pasif mendengarkan.

(2) Ada balikan bagi dosen, tidak ada interaksi di antara mahasiswa. Komunikasi dari dosen sudah mendapat respon balik dari mahasiswa, tetapi tidak ada interaksi antar mahasiswa. Interaksi yang terjadi hanya antara guru dan mahasiswa.

(3) Ada balikan bagi dosen, ada interaksi di antara mahasiswa. Komunikasi dari dosen sudah mendapat respon balik dari mahasiswa dan ada interaksi di antara mahasiswa, tetapi belum keseluruhan mahasiswa yang melakukan interaksi, baik dengan dosen maupun mahasiswa lainnya.

(4) Interaksi optimal antara dosen dengan mahasiswa dan antara mahasiswa dengan yang lainnya. Komunikasi sudah berjalan dengan baik antara guru dengan mahasiswa, maupun antara mahasiswa dengan yang lainnya. Interaksi yang terjadi sudah optimal selama proses pembelajaran.

\section{c. Project Based Learning}

Model pembelajaran berbasis proyek (project based learning)memiliki lima langkah pembelajaran (Marlinda, 2012), yaitu:

1) Menetapkan tema proyek. Tema proyek hendaknya memenuhi indikator, sebagai berikut: 1) memuat gagasan umum dan orisinil; 2) penting dan menarik; 3) mendeskripsikan masalah kompleks; dan 4) mencerminkan hubungan berbagai gagasan. Pada langkah pertama ini, yang lebih berperan adalah dosen sebagai fasilitator untuk menetapkan tema yang akan dipelajari mahasiswa selama proses pembelajaran.

2) Menetapkan konteks belajar. Konteks belajar hendaknya memenuhi indikator-indikator, sebagai berikut: 1) pertanyaan-pertanyaan proyek mempersoalkan masalah dunia nyata; 2) mengutamakan otonomi mahasiswa; 3) melakukan inquiry dalam konteks masyarakat; 4) mahasiswa mampu mengelola waktu secara efektif dan efisien; 5) mahasiswa belajar penuh dengan kontrol diri; dan 6) mensimulasikan kerja secara profesional. Pada tahap kedua ini, mahasiswa didorong untuk mampu mengeksplorasi kemampuannya dalam mengelola waktu dan bekerja secara kolaboratif.

3) Merencanakan aktivitas-aktivitas. Pengalaman belajar terkait dengan merencanakan proyek, sebagai berikut: 1) membaca; 2) meneliti; 3) observasi; 4) interviu; 5) merekam; 6) mengunjungi objek yang berkaitan dengan proyek; dan 7) akses internet. Pada tahap ketiga ini, mahasiswa yang telah memperoleh tema berkesempatan mencari sumber untuk mendesain proyek yang akan mereka kerjakan. Penelitian ini menekankan pada proyek berupa portfolio dan alat peraga.

4) Memproses aktivitas-aktivitas. Indikatorindikator memproses aktivitas, sebagai berikut: 1) membuat sketsa; 2) melukiskan analisa; 3 ) menghitung; dan 4) mengembangkan prototipe. Langkah ini memberikan kontribusi terhadap kinerja ilmiah, sebab dalam langkah ini indikator pertama kinerja ilmiah, yaitu merencanakan dan merancang. Perencanaan yang dilakukan mahasiswa sejalan pada tahap ketiga, hanya saja pada tahapan ini perencanaan lebih dibuat khusus, seperti pembuatan langkah-langkah praktikum. Untuk tahap merancang, dilakukan pada saat praktikum, yaitu pada saat merangkai alat.

5) Penerapan aktivitas-aktivitas untuk menyelesaikan proyek. Langkah-langkah yang dilakukan, antara lain: 1) mencoba mengerjakan proyek berdasarkan sketsa; 2) menguji langkah-langkah yang telah dikerjakan dan hasil yang diperoleh; 3) mengevaluasi hasil yang telah diperoleh; 4) merevisi hasil yang telah diperoleh; 5) melakukan daur ulang proyek yang lain; dan 6) mengklasifikasi hasil terbaik. Langkah kelima memberikan kontribusi pada kinerja ilmiah, yaitu menggunakan peralatan, pelaksanaan pengukuran, observasi dan pencatatan data, interpretasi dan tanggung jawab.

\section{Metode}

Penelitian ini merupakan kuasi eksperimen dengan menggunakan kelompok eksperimen dan kontrol. Desain penelitiannya adalah pretest-posttest control group design (Fraenkel \& Wallen, 1990).

$\begin{array}{lll}\mathrm{O} & \mathrm{X} & \mathrm{O} \\ \mathrm{O} & - & \mathrm{O}\end{array}$

Keterangan:

$\mathrm{O}=$ Pretes dan postes tes akhir semester

$\mathrm{X}=$ Pembelajaran dengan project based learning

- $\quad=$ Pembelajaran dengan metode ekspositori 
Kelompok eksperimen memperoleh perlakuan berupa model pembelajaran dengan project based learning dan kelompok kontrol memperoleh pembelajaran dengan metode ekspositori.Penelitian ini akan dilaksanakan di dua kelas reguler angkatan 2014 program studi pendidikan matematika STKIP Siliwangi Bandung. Subjek penelitian berjumlah sekitar 120 mahasiswa yang terdiri dari kelas A1 dan A3.

Teknik pengambilan sampel dilakukan secara purposive, karena penelitian ini diterapkan pada kelas yang mengambil mata kuliah media pembelajaran matematika, agar sesuai dengan penerapan pembelajaran berbasis proyek berupa alat peraga nantinya.Instrumen dalam penelitian ini adalah tes hasil belajar dan lembar observasi mahasiswa.

\section{HASIL DAN PEMBAHASAN}

\section{Hasil Penelitian}

\section{a. Data Prestasi Belajar Mahasiswa}

Data prestasi belajar mahasiswa terdiri dari data pretes dan postes. Berdasarkan data pretes dan postes dapat diketahui peningkatan prestasi mahasiswa sebelum dan sesudah memperoleh pembelajaran. Pada Tabel 1 berikut ini disajikan data pretes dan postes kelas eksperimen dan kontrol.
Apabila rerata pretes dan postes tidak berdistribusi normal, pengujian dilanjutkan dengan uji nonparametrik menggunakan Uji Mann-Whitney.

\section{1) Data Pretes Prestasi Belajar}

a) Uji Normalitas

Pada Tabel 2 berikut ini, disajikan hasil uji normalitas rerata pretes kelas eksperimen dan kontrol.

Tabel 2. Uji Normalitas Data Pretes

\begin{tabular}{llccc}
\hline \multirow{2}{*}{ Pretes } & \multicolumn{3}{c}{ Kolmogorov-Smirnov } \\
& & Statistic & df & Sig. \\
\hline \multirow{2}{*}{ Nilai } & Eksperimen & 0,210 & 43 & 0,000 \\
& Kontrol & 0,113 & 38 & 0,200 \\
\hline
\end{tabular}

Berdasarkan Tabel 2, pada taraf signifikansi 0,05 terlihat bahwa rerata pretes kelas eksperimen memiliki signifikansi (Sig.), yaitu $0,002<0,05$. Ini menunjukkan bahwa rerata pretes kelas eksperiman dan kontrol tidak berdistribusi normal. Selanjutnya, dilakukan uji perbedaan dua rerata pretes menggunakan Uji Mann-Whitney.

\section{b) Uji Mann-Whitney}

Setelah diperoleh rerata pretes tidak berdistribusi normal, selanjutnya dilakukan Uji Mann-Whitney. Pada Tabel 3 di bawah ini diperoleh hasil Uji Mann-Whitney, sebagai berikut:

Tabel 1. Rekapitulasi Data Pretes dan Postes

\begin{tabular}{lcccccccccccc}
\hline \multicolumn{1}{c}{ Kelas } & \multirow{n}{*}{$\boldsymbol{n}$} & Skor & \multicolumn{3}{c}{ Pretes } & \multicolumn{6}{c}{ Postes } & \multirow{2}{*}{ N-gain } \\
\hline Eksperimen & 43 & 100 & $\boldsymbol{x}_{\min }$ & $\boldsymbol{x}_{\text {maks }}$ & $\overline{\boldsymbol{x}}$ & $\boldsymbol{s}$ & $\boldsymbol{x}_{\min }$ & $\boldsymbol{x}_{\text {maks }}$ & $\overline{\boldsymbol{x}}$ & $\boldsymbol{s}$ & \\
Kontrol & 36 & 100 & 30 & 75 & 53,63 & 9.66 & 80 & 90 & 85,81 & 3,77 & 84,57 \\
\hline
\end{tabular}

Berdasarkan informasi yang terdapat pada Tabel 1 terlihat bahwa selisih rerata pretes antara kelas eksperimen dan kontrol adalah 3,39. Selisih rerata postes antara kelas eksperimen dan kontrol setelah pembelajaran diterapkan pada masing-masing kelas terjadi peningkatan menjadi 11,86 . Selisih rerata peningkatan skor pretes dan postes antara kelas eksperimen dan kontrol adalah 11,78. Untuk mengetahui apakah terdapat persamaan antara rerata pretes dan perbedaan rerata peningkatan skor postes secara signifikan digunakan uji $t$. Sebelum melakukan uji $t$, terlebih dahulu dilakukan uji prasyarat, yaitu uji normalitas dan uji homogenitas.

\begin{tabular}{lr} 
Tabel 3. Uji Mann-Whitney Data Pretes \\
\hline & \multicolumn{1}{c}{ Nilai } \\
\hline Mann-Whitney U & 654,500 \\
Wilcoxon W & 1395,500 \\
Z & $-1,557$ \\
Asymp. Sig. (2-tailed) & 0,119 \\
\hline
\end{tabular}

Berdasarkan Tabel 3, pada taraf signifikansi 0,05 terlihat bahwa signifikansi (Asymp.Sig.), yaitu $0,119>0,05$. Dapat disimpulkan bahwa tidak terdapat perbedaan antara rerata pretes prestasi belajar mahasiwa di kelas eksperimen dan kontrol. 


\section{2) Data Postes Prestasi Belajar}

a) Uji Normalitas

Pada Tabel 4 berikut ini, disajikan hasil uji normalitas rerata postes kelas eksperimen dan kontrol.

Tabel 4. Uji Normalitas Data Postes

\begin{tabular}{llccc}
\hline \multirow{2}{*}{ Pretes } & \multicolumn{3}{c}{ Kolmogorov-Smirnov } \\
& & Statistic & df & Sig. \\
\hline \multirow{2}{*}{ Nilai } & Eksperimen & 0,239 & 43 & 0,000 \\
& Kontrol & 0,161 & 38 & 0,015 \\
\hline
\end{tabular}

Berdasarkan Tabel 4, pada taraf signifikansi 0,05 terlihat bahwa rerata postes kelas eksperimen dan kontrol masing-masing memiliki signifikansi (Sig.), yaitu $0,000<0,05$ dan $0,015<0,05$. Ini menunjukkan bahwa rerata postes kelas eksperimen dan kontrol tidak berdistribusi normal. Selanjutnya, dilakukan uji perbedaan dua rerata postes menggunakan Uji Mann-Whitney.

b) Uji Mann-Whitney

Setelah diperoleh rerata pretes tidak berdistribusi normal, selanjutnya dilakukan Uji Mann-Whitney. Pada Tabel 5 di bawah ini diperoleh hasil Uji Mann-Whitney, sebagai berikut:

Tabel 5. Uji Mann-Whitney Data Postes

\begin{tabular}{lr}
\hline & \multicolumn{1}{c}{ Nilai } \\
\hline Mann-Whitney U & 235,500 \\
Wilcoxon W & 976,500 \\
Z & $-5,653$ \\
Asymp. Sig. (2-tailed) & 0,000 \\
\hline
\end{tabular}

Berdasarkan Tabel 5, pada taraf signifikansi 0,05 terlihat bahwa signifikansi (Asymp.Sig.), yaitu $0,000<0,05$. Dapat disimpulkan bahwa prestasi belajar mahasiswa yang memperoleh pembelajaran dengan project based learning lebih baik daripada yang memperoleh pembelajaran dengan metode ekspositori.

\section{3) Data N-gain Prestasi Belajar}

a) Uji Normalitas

Pada Tabel 6 berikut ini, disajikan hasil uji normalitas rerata $\mathrm{N}$-gain kelas eksperimen dan kontrol.
Tabel 6. Uji Normalitas Data N-gain

\begin{tabular}{llccc}
\hline \multirow{2}{*}{ Pretes } & \multicolumn{3}{c}{ Kolmogorov-Smirnov } \\
& & Statistic & df & Sig. \\
\hline \multirow{2}{*}{ Nilai } & Eksperimen & 0.210 & 43 & 0.000 \\
& Kontrol & 0.123 & 39 & 0,144 \\
\hline
\end{tabular}

Berdasarkan Tabel 6, pada taraf signifikansi 0,05 terlihat bahwa rerata $\mathrm{N}$-gain kelas eksperimen memiliki signifikansi (Sig.), yaitu $0,000<0,05$. Ini menunjukkan bahwa rerata pretes kelas eksperiman dan kontrol tidak berdistribusi normal. Selanjutnya, dilakukan uji perbedaan dua rerata Ngain menggunakan Uji Mann-Whitney.

\section{b) Uji Mann-Whitney}

Setelah diperoleh rerata $\mathrm{N}$-gain tidak berdistribusi normal, selanjutnya dilakukan Uji Mann-Whitney. Pada Tabel 7 di bawah ini diperoleh hasil Uji Mann-Whitney, sebagai berikut:

Tabel 7. Uji Mann-Whitney Data N-gain

\begin{tabular}{lr}
\hline & \multicolumn{1}{c}{ Nilai } \\
\hline Mann-Whitney U & 264,000 \\
Wilcoxon W & 1044,000 \\
Z & $-5,340$ \\
Asymp. Sig. (2-tailed) & 0,000 \\
\hline
\end{tabular}

Berdasarkan Tabel 7, pada taraf signifikansi 0,05 terlihat bahwa signifikansi (Asymp.Sig.), yaitu $0,000<0,05$. Rerata peningkatan prestasi belajar mahasiswa kelas eksperimen lebih baik daripada kelas kontrol. Dapat disimpulkan bahwa peningkatan prestasi belajar mahasiswa yang memperoleh pembelajaran dengan project based learning lebih baik daripada yang memperoleh pembelajaran dengan metode ekspositori.

\section{b. Data Keaktifan Mahasiswa}

Data keaktifan mahasiswa ditentukan dari banyaknya mahasiswa yang bertanya atau menjawab selama diskusi berlangsung pada setiap pertemuan. Berdasarkan hasil pengamatan di kelas eksperimen dan kontrol mengenai keaktifan mahasiswa dalam pembelajaran diperoleh persentase pada Tabel 8, sebagai berikut:

Tabel 8. Hasil Pengamatan Keaktifan Mahasiswa

\begin{tabular}{cccc}
\hline \multirow{2}{*}{ No. } & \multicolumn{2}{c}{ Pengamatan } & \multicolumn{2}{c}{ Persentase } \\
Eksperimen & Kontrol \\
\hline 1. & $\begin{array}{l}\text { Mahasiswa terlibat } \\
\text { dalam kegiatan yang } \\
\text { diberikan }\end{array}$ & 78,00 & 72,37 \\
\hline
\end{tabular}


pembelajaran.

2. Mahasiswa bertanya jika ada materi yang

$76,25 \quad 73,03$ belum dipahami.

3. Mahasiswa

menjawab

pertanyaan dosen

atau teman lain.

4. Mahasiswa diam

ketika teman

kelompoknya saling berdiskusi.

\section{Rerata} 70,93

69,41

Berdasarkan Tabel 8, terlihat bahwa rerata persentase keaktifan mahasiswa kelas eksperimen dengan pembelajaran project based learning $(70,93 \%)$ lebih tinggi daripada kelas kontrol dengan metode ekspositori $(69,41)$. Terdapat selisih sebesar 1,20. Selisih ini bukan berarti bahwa keaktifan mahasiswa di kelas kontrol kurang baik, karena persentase keaktifan mahasiswa di kelas kontrol sebesar $69,41 \%$ melebihi persentase nilai tengahnya, yaitu $50 \%$.

\section{Pembahasan}

Mahasiswa yang memperoleh pembelajaran dengan project based learning memperoleh prestasi belajar yang lebih baik daripada yang memperoleh pembelajaran dengan metode ekspositori. Dalam pembelajaran dengan project based learning mahasiswa diminta mempelajari materi terlebih dahulu bedasarkan silabus yang sudah diberikan dosen dengan membuat rangkuman sebelum didiskusikan bersama di dalam kelas. Kegiatan ini dapat membuat mahasiswa memiliki pengetahuan awal yang baik sebelum dijelaskan oleh dosen melalui presentasi dan diskusi. Rangkuman yang dibuat mahasiswa nantinya dinilai oleh dosen. Bagi mahasiswa yang tidak membuat rangkuman akan memperoleh pengurangan nilai, dengan demikian mereka yang menginginkan nilai yang memuaskan mesti mempelajari materi dan merangkumnya.

Setelah mahasiswa mengumpulkan rangkuman materi yang akan dipelajari, dosen memilih secara acak mahasiswa untuk mempresentasikan di depan kelas. Kondisi ini membuat setiap mahasiswa mempersiapkan diri untuk menyampaikan pemahaman mereka mengenai materi yang telah dirangkum tersebut. Sementara itu, mahasiswa lain memperhatikan dan mempersiapkan pertanyaan apabila ada materi yang tidak dimengerti setelah temannya mempresentasikan. Mereka juga diminta untuk memberikan masukan dan tambahan terkait materi yang dipelajari apabila terdapat kekurangan dari yang disampaikan temannya.

Setelah mahasiswa yang ditunjuk selesai mempresentasikan materi, selanjutnya dosen meminta mahasiswa mendiskusikan. Dalam proses diskusi, mahasiswa terlibat aktif dalam memahami bersama materi yang sedang dipelajari. Dosen mengamati mahasiswa yang aktif dalam pembelajaran dan memberikan penjelasan apabila terjadi kekeliruan dari jawaban yang diberikan mahasiswa. Jika keadaan ini terus menerus dialami oleh mahasiswa, akan menyebabkan pemahamannya terhadap materi yang dipelajari menjadi lebih baik dan berdampak terhadap nilai akhir mereka yang memuaskan.

Berbeda dengan kegiatan pembelajaran yang menggunakan metode ekspositori. Mahasiswa tidak diminta untuk mengumpulkan rangkuman mengenai materi yang dipelajari. Dosen hanya menyampaikan kepada mahasiswa untuk mempelajari materi yang akan diajarkan. Hal ini tidak membuat mahasiswa untuk belajar karena mereka mengetahui tidak akan diberi sangsi nilai apabila mereka tidak merangkum. Ketika dosen menyampaikan materi di depan kelas, mahasiswa tentu ada yang belajar dan tidak belajar sebelumnya, sehingga mereka tidak dapat memahami materi dengan baik karena pengetahuan awalnya tentang materi itu tidak ada. Kondisi ini dapat menyebabkan mahasiswa jenuh di kelas karena tidak terlibat aktif dalam pembelajaran. Mulailah mereka melakukan aktivitas lain, seperti mengobrol dengan teman sebelah, tidur di kursi, dsb.

Apabila situasi ini terjadi terus menerus dalam pembelajaran, tentu akan berdampak terhadap pemahaman mahasiswa tehadap materi menjadi tidak baik dan nilai akhir mereka menjadi kurang memuaskan. Berdasarkan nilai akhir mahasiswa, diperoleh data bahwa mahasiswa yang memperoleh nilai sangat memuaskan di kelas eksperimen lebih banyak dari pada di kelas kontrol. Sebanyak 20 mahasiswa di kelas eksperimen memperolah nilai A, sedangkan di kelas kontrol hanyak 7 mahasiswa yang memperoleh nilai A. Kondisi ini menjelaskan bahwa pembelajaran dengan project based learning mengakomodasikan dan mendorong setiap mahasiswa untuk memahami materi melalui 
rangkuman dan diberi kesempatan yang sama untuk terlibat aktif dalam presentasi dan diskusi.

Pada pembelajaran dengan metode ekspositori, mahasiswa yang terlibat aktif adalah mereka yang terbiasa belajar sendiri. Mereka mempelajari materi terlebih dahulu tanpa diminta dosen, sehingga ketika terjadi diskusi mereka sudah mempersiapkan diri untuk bertanya dan berpendapat. Dosen mesti memberikan nilai tambahan bagi setiap mahasiswa yang terlibat aktif dalam diskusi sebagai motivasi bagi mereka memperoleh nilai yang sangat memuaskan.

Pada mahasiswa yang memperoleh pembelajaran dengan metode ekspositori, hanya sebagian kecil mahasiswa yang memperoleh nilai sangat memuaskan, karena mereka tidak didorong untuk sungguh-sungguh belajar seperti yang diterapkan dalam project based learning. Semestinya dosen perlu memotivasi mahasiswa lain yang belum terbiasa aktif dengan memberikan kesempatan bagi mereka untuk memberikan pertanyaan atau menyampaikan pendapat pada saat diskusi di kelas. Mahasiswa yang mulai memiliki keberanian dalam bertanya dan berpendapat mesti terus dimotivasi dengan meminta mereka untuk selalu berpartisipasi aktif selama pembelajaran. Untuk dapat berpartisipasi aktif, tentu mahasiswa tersebut mempelajari terlebih dahulu materi yang akan didiskusikan.

Berdasarkan wawancara dengan beberapa mahasiswa yang memperoleh pembelajaran dengan project based learning, mereka merasa tertekan untuk membuat rangkuman sebelum materi didiskusikan bersama-sama dengan dosen. Sesuai dengan data pada pandangan mahasiswa terhadap pembelajaran, rerata sebesar 3,05 (76,25\%) mahasiswa lebih menyukai dosen yang menjelaskan dan mereka hanya mendengarkan saja. Ini disebakan karena mereka belum terbiasa mempersiapkan diri untuk belajar. Mereka lebih suka belajar di kelas tanpa persiapan.

Kondisi ini tidak baik terus berlanjut. Dosen mesti merubah paradigma mahasiswa yang hanya belajar ketika di kelas dan menghadapi ujian saja. Setelah mahasiswa memperoleh pembelajaran dengan project based learning mereka menjadi terbiasa mempelajari materi secara mandiri, aktif bertanya dan berpendapat apabila ada materi yang belum mereka pahami, serta dapat meraih prestasi belajar yang sangat memuaskan sebagai hasil dari usaha mereka sendiri.

\section{KESIMPULAN}

Berdasarkan hasil penelitian dan pembahasan mengenai prestasi belajar dan keaktifan mahasiswa terhadap pembelajaran dengan project based learningdiperoleh kesimpulan, sebagai berikut:

1. Prestasi belajar mahasiswa yang memperoleh pembelajaran dengan project based learning lebih baik daripada yang memperoleh pembelajaran dengan metode ekspositori.

2. Keaktifan mahasiswa yang memperoleh pembelajaran dengan project based learning lebih baik daripada yang memperoleh pembelajaran dengan metode ekspositori.

Berdasarkan kesimpulan yang diperoleh, penulis mengemukakan beberapa saran sebagai berikut:

a. Pembelajaran dengan project based learnign dapat dijadikan sebagai salah satu alternatif dalam meningkatkan prestasi belajar mahasiswa dan membuat mahasiswa aktif dalam diskusi di kelas.

b. Dosen mesti memberikan reward berupa nilai tambahan bagi setiap mahasiswa yang berpartisipasi aktif dengan mencatat langsung nama mereka di daftar nilai. Tindakan ini dapat menumbuhkan semangat dan motivasi bagi mahasiswa lain untuk ikut aktif dalam pembelajaran.

c. Dalam pembelajaran, mesti diatur waktu untuk mahasiswa melakukan presentasi dengan berdiskusi. Apabila terlalu lama presentasi, mahasiswa yang mendengarkan menjadi jenuh dan waktu untuk diskusi menjadi sedikit, sehingga keaktifan siswa untuk tanya jawab menjadi tidak optimal.

d. Dosen mesti selalu memantau proses diskusi mahasiswa, karena ketika mahasiswa berdiskusi dan tanya jawab, dapat terjadi kekeliruan sehingga menyebabkan kebingunan bagi mahasiswa. Di sini lah peran dosen memberikan penjelasan yang benar agar mahasiswa dapat memahami materi dengan baik.

e. Dosen mesti menyimpulkan kembali hasil diskusi dari mahasiswa agar tercipta kesamaan pendapat dan tidak ada mahasiswa yang mengalami kesalahan dalam memahami materi perkuliahan. 


\section{E. DAFTAR PUSTAKA}

Azwar, S. (1998). Tes Prestasi II. Yogyakarta: Pustaka Belajar.

Creswell, J. (2008). Educational Research: Planning, Conducting, and Evaluating Quantitative and Qualitative Research. New Jersey: Pearson-Merrill Prentice Hall.

Dalyono. (2005). Psikologi Pendidikan.Jakarta: Rineka Cipta.

Fraenkel, J. C. \& Wallen, N. E. (1990). How to Design and Evaluate Research in Education.New York: McGraw-Hill.

Hake, R. R. (1999). Analyzing Change/Gain Scores.[Online]. Tersedia di: http: //www.physics.indiana.edu/ sdi/Analyzin gchange-Gain.pdf. Diakses 23September 2015).

Hamalik, O. (2006). Proses Belajar Mengajar.Jakarta: Bumi Aksara.

Marlinda, N. L. P. M. (2012). Pengaruh Model Pembelajaran Berbasis Proyek terhadap Kemampuan Berpikir Kreatif dan Kinerja Ilmiah Siswa. (Tesis). Program Pascasarjana, Universitas Pendidikan Ganesha, Denpasar.

Meltzer, D. E. (2002). "The Relationship between Mathematics Preparation and Conceptual Learning Gain in Physics: A Possible "HiddenVariable" in Diagnostics Pretest Scores". American Journal of Physics. Vol. 70 (12) 1259-1268.

Poerwadarminta, W. J. S. (2006). Kamus Umum Bahasa Indonesia.Jakarta: Balai Pustaka.

Siegel, I. E. (1985). Parental Beliefs System: The Psychological Consequences for Children. Hill Sedlle, HJ: Erlbaum.

Sudjana, N. (2005). Dasar-Dasar Proses Belajar Mengajar. Bandung: Sinar Baru Algesindo.

Usman, M. U. (2002). Menjadi Guru Profesional.Bandung: Remaja Rosdakarya.

Wena, M. (2011). Strategi Pembelajaran Inovatif Kontemporer: Suatu Tinjauan Konseptual Operasional. Jakarta: Bumi Aksara. 